\title{
The Influence of Diet on Mercury Intake by Little Tern Chicks
}

\author{
Vitor H. Paiva - Paula C. Tavares $\cdot$ Jaime A. Ramos $\cdot$ Eduarda Pereira \\ Sandra Antunes $\cdot$ Armando C. Duarte
}

Received: 21 October 2007 / Accepted: 14 December 2007/Published online: 9 January 2008

(C) Springer Science+Business Media, LLC 2008

\begin{abstract}
We assessed mercury levels in the feathers of little tern (Sternula albifrons) chicks from hatching to fledging and in their prey captured by adults in three main foraging habitats: lagoon, salinas, and adjacent sea. These data were used to model mercury concentration in chick feathers through food ingestion, in order to explore the effects that changes in diet would have on the mercury burden of chicks as they aged. The mercury concentration in feathers of chicks raised in sandy beaches was higher than in those raised in salinas. Lagoon prey had a significantly higher mercury concentration $\left(0.18 \pm 0.09 \mu \mathrm{g} \mathrm{g}^{-1}\right.$ dry weight [d.w.]) than prey from salinas and the adjacent sea (both $0.06 \pm 0.03 \mu \mathrm{g} \mathrm{g}^{-1}$ d.w.). In relation to prey species group, mercury content was significantly higher for bottom fish $\left(0.17 \pm 0.10 \mu \mathrm{g} \mathrm{g}^{-1}\right.$ d.w. $)$ than for pelagic $(0.08 \pm 0.06$ $\mu \mathrm{g} \mathrm{g}^{-1}$ d.w. $)$, euryhaline fish $\left(0.04 \pm 0.02 \mu \mathrm{g} \mathrm{g}^{-1}\right.$ d.w. $)$, and crustacea $\left(0.08 \pm 0.03 \mu \mathrm{g} \mathrm{g}^{-1}\right.$ d.w.). To understand the importance of mercury content of each prey group, we ran several theoretical scenarios assuming that chicks were fed on only one species at a time. Considering a diet restricted to lagoon (mostly benthic) prey, $A$ - and $B$-chicks may encounter health problems with an excess of mercury. On the contrary, a diet restricted to marine (mostly pelagic) prey would decrease the mercury concentration in chick feathers;
\end{abstract}

\footnotetext{
V. H. Paiva ( $₫)$ J. A. Ramos · S. Antunes IMAR-Instituto do Mar, Department of Zoology, University of Coimbra, 3004-517 Coimbra, Portugal e-mail: vitorpaiva@ci.uc.pt

P. C. Tavares - E. Pereira - A. C. Duarte Department of Chemistry, University of Aveiro, 3810-193 Aveiro, Portugal

P. C. Tavares

CVRM, IST, Av. Rovisco Pais, 1049-001 Lisboa, Portugal
}

the fast growth rate and the related mercury dilution effect in little tern chicks seem to decrease mercury levels in their feathers. Our study supports the fact that marine pelagic prey are important for estuarine seabirds because they provide a food resource with lower contamination levels. This model may have a wider application in similar seabird species and coastal environments.

Mercury is a toxic heavy metal that bioamplifies in food webs (Bearhop et al. 2000; Burger and Gochfeld 2002, 2004). Deposition in feathers represents the major elimination pathway for accumulated mercury in birds; mercury in feathers is almost entirely in the form of methyl-mercury, and levels correlate well with body burdens (Thompson and Furness 1989a, 1989b; Furness and Camphuysen 1997). Mercury contamination in chicks is influenced by egg contamination, hatching order, chick age, and mercury uptake through food ingestion (Becker et at. 1993a, 1993b, 1994; Monteiro and Furness 1995; Wenzel et al. 1996; Stewart et al. 1997; Goutner et al. 2001). Mercury levels in hatchlings are influenced by the mercury burdens present in the female, because $20 \%$ of body contamination is released into the egg in the week before laying (Lewis et al. 1993). As chicks' age increases, the importance of diet for mercury burden in chick tissues also increases (Wenzel et al. 1996). In general, mercury decreases in chicks as they grow due to a fast increase in body mass, which represents a dilution effect (Becker et al. 1994). This effect is likely to be very important during the initial fast growing period in chicks (Konarzewski et al. 1998). Tavares et al. (2005) obtained a significant negative correlation between mercury levels in feathers and chick size in little tern Sternula albifrons, which suggests a strong dilution effect. However, their samples did not 
include intermediate chick size classes. Thyen et al. (2000) studied mercury contamination of little tern chicks on the western coast of the Baltic Sea but only sampled chicks 03 days of age. Studies on the dynamics of mercury in chicks reared in the laboratory were performed for some seabird species such as the black-headed gull Larus ridibundus (Lewis and Furness 1991) and common loon Gavia immer (Kenow et al. 2003). Monteiro and Furness (2001) fed Cory's shearwater Calonectris diomedea borealis chicks with increasing doses of mercury and analyzed their growing feathers to evaluate the dilution effect.

Mercury intake through food ingestion is considered to be the main factor determining mercury contamination in fledglings, and the influence of egg contamination is considered negligible for old chicks (Becker et al. 1993a, 1993b; Monteiro and Furness 1995; Wenzel et al. 1996). Chicks may be useful as biomonitors of mercury contamination in a restricted area because they are confined to a particular site before independence, their parents deliver prey caught around the breeding grounds (Cramp 1985; Allcorn et al. 2003), and their feathers are easy to sample. Breeding little terns feed within $4 \mathrm{~km}$ of their colonies (Fasola and Bogliani 1990; Allcorn et al. 2003), where they take the most abundant prey (Catry et al. 2006). Hence, they are likely to be a good bioindicator of environmental contamination in the coastal area around the colonies. Therefore, it is important to understand the exact details of the relationships between mercury in chick prey and mercury in their feathers (Arcos et al. 2002).

In this paper we examine little tern chick provisioning from hatching to fledging and assess mercury levels in the feathers of those same chicks, and in their prey, at the ages of $0,4,9,14$, and 17 days, in order to answer the following questions: (a) Do the mercury levels in growing chicks relate to those of their prey? (b) How important is the dilution effect in determining mercury contamination in large chicks? and (c) What is the contribution of different prey items to the mercury burden in feathers of little tern chicks? To examine the latter point we built a model of mercury release into chick feathers to assess the capacity of the chicks to dilute and excrete into feathers the mercury ingested from their prey.

\section{Methods}

\section{Study Area}

Ria Formosa Natural Park is situated on the south coast of Portugal, Algarve $\left(37^{\circ} 06^{\prime} \mathrm{N}, 7^{\circ} 38^{\prime} \mathrm{W}\right)$, and consists of a complex tidal system of natural and seminatural channels (lagoon), marshland, and barrier islands covering an area of 18,400 ha along $60 \mathrm{~km}$ of coast. In the margins of the marshland area, there are manmade ponds which represent salinas (saltpans) and extensive fish farms. Close to the park's northern borders are the three large towns Faro, Olhão, and Tavira. Our observations took place in both natural (sandy beaches of the barrier islands Armona, Faro, and Barreta) and alternative (salinas around Santa Luzia, Tavira) breeding habitats (Catry et al. 2004). The closest foraging areas were the lagoon and the sea for birds breeding in natural habitats and the lagoon and salinas for those breeding in alternative habitats.

\section{Food Delivery}

During regular visits to the colonies on sandy beaches (Armona, Barreta, Praia de Faro) and salinas (Santa Luzia I, Santa Luzia II, Arraial Ferreira Neto, Vale Carangueijo) in 2005; 42 dropped prey items (these include prey that were not ingested) were collected and each prey item was immediately placed in a new plastic bag. All specimens were identified to the lowest taxonomic level based on available identification keys. Food delivery to 10 fenced broods in salinas was observed from 10 June to 3 July 2005. Two portable hides, placed 2-7 $\mathrm{m}$ from these nests, were used to observe and identify prey delivered to chicks, using $10 \times 40$ binoculars. A total of $90 \mathrm{~h}$ of observations was made, divided into periods of 1 to $10 \mathrm{~h}$ (mean $=2 \mathrm{~h}$ ). The observations were randomly spread across the 3-week period, the daylight hours, and the tidal phases. Each nest was sampled equally (same number of hours per nest; see Paiva et al. [2006a] for further details on food delivery procedures). During the breeding season of 2005, the main prey items delivered to chicks were Sardina pilchardus, Atherina spp., and shrimp (Paleomon spp. and Paleomonetes spp.), comprising almost $74 \%$ of the diet. Also, prey items comprising each $<5 \%$ of the diet were Belone belone, Fundulus spp., Pomatoschistus spp., and Scomberesox saurus (Paiva et al. 2006b). The length of each prey delivered was determined in relation to the mean little tern adult bill length (Paiva et al. 2006a) and transformed into mass using regression equations (Table 1). Further details on chick growth and food delivery to chicks are given by Paiva et al. (2006a, 2006b).

\section{Sample Collection and Preparation}

Samples of down and breast feathers were collected from 64 little tern chicks from different colonies in salinas and sandy beaches, during the 2004 and 2005 breeding seasons. Sampled chicks were weighed $(\mathrm{g})$, and their wing length and tarsus length were measured (mm). In 2005 we sampled down and feathers from chicks of 14 fenced nests in salinas of Sta. Luzia at $0,4,9,14$, and 17 days of age. 
Table 1 Regression equations for the species used in the model: total length $(T L ; \mathrm{cm})$ and weight $(W ; \mathrm{g}$, fresh weight)

\begin{tabular}{lll}
\hline Species & $T L-W$ regression & Reference \\
\hline Atherina spp. & $W=0.0069 \times T L^{3}$ & Fishbase (2007) \\
Sardina pilchardus & $W=0.0060 \times T L^{3}$ & Fishbase (2007) \\
Belone belone & $W=0.0020 \times T L^{2.87}$ & Fishbase (2007) \\
Fundulus spp. & $W=0.0142 \times T L^{3}$ & Fishbase (2005) \\
Scomberesox saurus & $W=0.0015 \times T L^{3.19}$ & Fishbase (2007) \\
Pomatoschistus spp. & $W=0.0142 \times T L^{3}$ & Fishbase (2007) \\
Shrimp & $W=0.0042 \times T L^{2.4}$ & Unpublished data \\
\hline
\end{tabular}

Feather samples were collected from $A$-, $B$-, and $C$-chicks ( $n=12,11$, and 5 , respectively). Chicks were designated $A, B$, or $C$ according to hatching order (when two chicks hatched on the same day, we considered the $A$-chick as the one hatching from the largest egg, which had a greater body mass and greater tarsus length). Body mass ( $g$ ) for each fenced chick was obtained daily (Paiva et al. 2006b). Prey samples were collected directly from food delivered to chicks in the breeding ground, stored at $-20^{\circ} \mathrm{C}$, and dried until constant weight. To give strong consistency to the mean mercury level of each prey species, we analyzed prey collected in several colonies at Ria Formosa as laboratory replicates and, also, analyzed mercury levels for prey collected in salinas of other coastal Portuguese wetlands where little terns breed, the Tejo and Sado estuaries.

\section{Mercury Determinations}

Total mercury concentration was determined in down, feather, and prey samples by thermal atomization followed by atomic absorption spectroscopy using an AMA254 spectrophotometer (Althec, Czech Republic). Accuracy of the method was within $10 \%$ of the reference value, and it was monitored through reference materials, NIES-5 (human hair, $4.4 \pm 0.4 \mu \mathrm{g} \mathrm{g}^{-1}$ ) and TORT-2 (lobster hepatopancreas, $0.27 \pm 0.06 \mu \mathrm{g} \mathrm{g}^{-1}$ ), with a $95 \%$ confidence interval. The uncertainty was assessed by performing successive measurements with the same sample, and relative standard deviations in the range of $5 \%$ were found. The detection limit was established as $0.01 \mathrm{ng} \mathrm{Hg}$ for $0.100 \mathrm{~g}$ samples $(0.1 \mathrm{ng}$ $\mathrm{g}^{-1}$ ) by Althec. Mercury concentrations were given on a fresh weight (f.w.) basis in down and feather samples and a dry weight (d.w.) basis in prey samples.

\section{Model Building}

The model takes into account the total mercury content of the main prey items (formerly described), derived from their biomass and specific mercury concentration, and the prey delivery rate to chicks, contributing to a pool of mercury to be divided among $A-, B$-, and $C$-chicks based on a competition factor. This factor assumes that larger chicks have a higher chance of getting food because they have a higher fitness than smaller chicks (Shew and Ricklefs 1998); this was confirmed during our observations as well. The competition also included a hatching delay factor: the $B$ - and $C$-chicks hatched $0.29 \pm 0.03$ and $0.87 \pm 0.05$ day later then the $A$-chicks (mean value \pm SD obtained from the fenced nests in 2003). Those values were set in the model to create a delay in the available energy flow to $B$ - and $C$-chicks (Paiva et al. $2006 b)$. Each chick allocates some portion of mercury to down and new grown feathers $(\sim 38 \%$ [Becker et al. 1993a]). The maximum allocation of mercury to feathers or other chick tissues is regulated by the balance between mercury inputs through food ingestion and a dilution effect associated with chick growth (Becker et al. 1994). In order to take this into account we used an energetic balance growth model previously developed by Paiva et al. (2006b) for little tern chicks and collected feathers of the same individual chicks from hatching to fledging. To build the model of mercury release into feathers we used the chick growth rate and the maximum weight of chicks from the growth model constructed by Paiva et al. (2006b). Although we had no independent data to validate our model according to different initial conditions and respective outputs, we believe that the output from the theoretical scenarios tested with this model may help in understanding how little tern chicks allocate the mercury ingested and assimilated from prey delivered by their parents, and how the parents' choices may influence chicks' mercury burdens and, thus, their potential health and body fitness. The model was constructed using STELLA (High Performance Systems Inc. 1997) v7.03 software .

The model building procedure then followed 11 main steps. (1) From significant regressions obtained in the literature and in Fishbase (2007) (Table 1), it was possible to determine the mass of each prey from its length (Table 2). (2) The biomass of each prey was multiplied by the mean mercury concentration of each prey species, which gives the mercury content relative to each prey. (3) To calculate the mean mercury rate delivered per day, the value delivered per hour for each species (Table 2) was multiplied by $13 \mathrm{~h}$, the number of daylight hours at this time of the year; parents do not deliver food at night (Davies 1981). (4) Total daily mercury available from all ingested prey was calculated from the sum of individual mercury content of each prey. (5) The total mercury available was then divided among three chicks from the same brood $(A-, B$-, and $C$ chicks), creating a pool of body mercury that enters each 
Table 2 Total mercury concentration ( $\mu \mathrm{g} \mathrm{g}^{-1}$ d.w.) of different prey species from little tern chicks

\begin{tabular}{|c|c|c|c|c|}
\hline Taxon (place of collection) & $\begin{array}{l}\mathrm{Hg} \text { concentration } \\
\text { (sample size) }\end{array}$ & $\begin{array}{l}\text { Mean foraging trip } \\
\text { duration }(\mathrm{h})\end{array}$ & Total length $(\mathrm{cm})$ & $\begin{array}{l}\text { Mass of meal delivered } \\
\text { (mass of prey/chick } / \mathrm{h} \text { ) }\end{array}$ \\
\hline \multicolumn{5}{|l|}{ Pelagic fish } \\
\hline Sardina pilchardus (Tejo) & $0.17 \pm 0.03(9)$ & & & \\
\hline Sardina pilchardus (Sado) & $0.18 \pm 0.06(7)$ & & & \\
\hline Sardina pilchardus (Ria Formosa) & $0.09 \pm 0.03(9)$ & $0.63 \pm 0.75(140)$ & $3.94 \pm 1.04(161)$ & $2.80 \pm 0.45(49)$ \\
\hline Atherina spp. (Ria Formosa) & $0.19 \pm 0.09$ & $0.47 \pm 0.77(303)$ & $5.10 \pm 1.86(365)$ & $0.88 \pm 0.43(68)$ \\
\hline Belone belone (Ria Formosa) & $0.03 \pm 0.01$ & $0.55 \pm 0.69$ & $7.57 \pm 2.06(54)$ & $1.70 \pm 0.80(26)$ \\
\hline Scomberesox saurus (Ria Formosa) & $0.04 \pm 0.01(6)$ & $0.75 \pm 0.74(52)$ & $4.94 \pm 2.46(60)$ & $0.24 \pm 0.08$ \\
\hline Mugilidae (Tejo) & $0.15 \pm 0.04$ & & & \\
\hline Mugilidae (Sado) & $0.11 \pm 0.00$ & & & \\
\hline Trachurus trachurus (Ria Formosa) & $0.09 \pm 0.00$ & & & \\
\hline \multicolumn{5}{|l|}{ Euryhaline fish } \\
\hline Fundulus spp. (Ria Formosa) & $0.04 \pm 0.02(2)$ & $0.50 \pm 0.55(51)$ & $3.01 \pm 0.27(57)$ & $0.42 \pm 0.10$ \\
\hline \multicolumn{5}{|l|}{ Crustacea } \\
\hline Paleomonetes spp. (Ria Formosa) & $0.08 \pm 0.03$ & $0.40 \pm 0.51(204)$ & $2.57 \pm 0.51(248)$ & $0.24 \pm 0.10(50)$ \\
\hline Paleomonetes spp. (Sado) & $0.08 \pm 0.07(17)$ & & & \\
\hline Paleomonetes spp. (Tejo) & $0.08 \pm 0.06(29)$ & & & \\
\hline Paleomonetes spp. (Aveiro) & $0.08(1)$ & & & \\
\hline \multicolumn{5}{|l|}{ Bottom/demersal fish } \\
\hline Pomatoschistus spp. (Ria Formosa) & $0.31 \pm 0.09$ & $0.37 \pm 0.42(53)$ & $2.85 \pm 0.38(131)$ & $0.33 \pm 0.11(21)$ \\
\hline Gambusia holbrooki (Tejo) & $0.28 \pm 0.24(5)$ & & & \\
\hline Symphodus melops (Ria Formosa) & $0.16 \pm 0.02$ & & & \\
\hline Diplodus spp. (Ria Formosa) & $0.08 \pm 0.01$ & & & \\
\hline Blenniidae (Ria Formosa) & $0.21 \pm 0.00$ & & & \\
\hline Spondyliosoma cantharus (Ria Formosa) & $0.12 \pm 0.03(2)$ & & & \\
\hline
\end{tabular}

Mean values $\pm \mathrm{SD}$, with samples size in parenthesis. Mean foraging trip duration, total length, and mean mass of meal delivered for all species except Pomatoschistus spp. and Scomberesox saurus (this study) were taken from Paiva et al. (2006b)

chick daily. (6) Then some part of this body mercury uptake $(43 \%, 39 \%$, and $38 \%$ for $A-, B-$, and $C$-chicks, respectively; values obtained by calibration) was allocated to new growing feathers as a way of mercury excretion. These values were set considering that Laridae chick feathers normally contain $38 \%-65 \%$ of the total mercury body burden (Lewis and Furness 1991; Becker et al. 1993a). (7) The logistic curve of mercury decrease, which has a sigmoid shape (very similar to an inverted logistic growth curve [Paiva et al. 2006b]), enables the description of mercury decrease in feathers of chicks as they grow (Wenzel et al. 1996). (8) The decrease rate constant $\left(K_{\mathrm{Hg}}=0.1566\right)$ was obtained by calibration with data collected in 2005. (9) We used the logistic growth rate constant obtained by Paiva et al. (2006b) for little tern chicks $\left(K_{\mathrm{G}}=0.0249 \pm 0.01\right)$ to associate the mercury decrease in chick feathers with growth. This represents in the model the dilution of the dietary mercury intake due to the increase in body mass. The association of the logistic growth rate with mercury dynamics enabled us to simulate the phase when chicks stop begging for food and parents respond by reducing feeding rate, as the food ingested and the amount of mercury uptake by the chicks will be limited by chick growth and satiation. (10) We used a minimum mercury concentration in feathers for $A-, B$-, and $C$-chicks as the value they usually attain by 17 days of age, $2.78 \pm 0.47,2.84 \pm 0.43$, and $3.16 \pm 0.34 \mu \mathrm{g} \mathrm{g}{ }^{-1}$ f.w. $( \pm \mathrm{SD})$, respectively (obtained from fieldwork, as chick feathers would never be completely free from mercury). Also, the asymptotic mass attained by $A-, B$-, and $C$-chicks, on days 20,19 , and 22 , was $43.0 \pm 1.34,42.4 \pm 1.32$, and $43.0 \pm 0.50 \mathrm{~g}( \pm \mathrm{SD})$, respectively. Most chicks began the asymptotic part of their growth at $15\left(t_{i}\right)$ days of age (Konarzewski et al. 1998; Starck and Ricklefs 1998). (11) Mercury concentrations in down feathers of recently hatched chicks were $10.37 \pm 3.89,6.93 \pm 1.38$, and $6.57 \pm 0.41 \mu \mathrm{g} \mathrm{g}^{-1}$ f.w. for $A$-, $B$-, and $C$-chicks, correspondingly. Hatching mass corresponded to measured mean values, $6.50 \pm 0.17,6.40 \pm 0.26$, and $6.16 \pm 0.31 \mathrm{~g}$ for $A-, B$-, and $C$-chicks, respectively. 
Sensitivity Analysis

To check for the most sensitive parameters (Table 3), we calculated the "individual parameter perturbation" (Madenjian and Gabrey 1995) described in the STELLA software manual (High Performance Systems, Inc. 1997), which examines the sensitivity of model performance to variation in model's parameter values. Changes of $\pm 10 \%$ were imposed on the model parameters and the consequent variations of mercury content in feathers of $A-, B-$, and $C$ chicks were analyzed.

\section{Theoretical Scenarios}

To understand the importance of the mercury content of each prey species, we ran the model assuming that chicks were fed only one single species at a time. For example, considering that an adult foraging trip for Atherina spp lasted $0.47 \mathrm{~h}$ (Table 2), and assuming that parents could forage during the $13 \mathrm{~h}$ of daylight, they could feed their chicks 6.11 Atherina spp. items per day. We also analyzed the effects of a diet restricted to lagoon prey on chicks' mercury levels, in relation to the effects of a diet of only marine items (but accounting for the extra foraging time parents' gain by not foraging on the omitted prey). In addition, we compared the effects of a diet of shrimp (crustacea) vs one of fish, and the effects of pelagic prey vs bottom prey, on chicks' mercury levels. Finally, we tested the effect of a typical diet of adults for that area on chicks' mercury levels, using the proportions of each prey type: 45.9\% of Pomatoschistus spp., 40.5\% of Atherina spp. and $13.6 \%$ of shrimp (Pomatoschistus spp. and Paleomonetes spp.), as obtained by Catry et al. (2006). A maximum value of $20 \mu \mathrm{g} \mathrm{g}^{-1}$ for the total mercury concentration in feathers, detected in the salinas of Santa Luzia in 2005, was used as a theoretical physiological limitation of chicks to passively allocate mercury to their feathers. In the references no threshold mercury value was found above which body condition and chick survival would be compromised in this species.

Table 3 Sensitivity analysis of the principal parameters entered in the model

\begin{tabular}{llrrr}
\hline Parameter & Value & $A$-chicks & $B$-chicks & $C$-chicks \\
\hline Constant of mercury decay & 0.1566 & 13.4346 & 12.8502 & 8.9701 \\
Intercept of mercury decay & 0.272 & 10.6470 & 11.4290 & 7.6760 \\
Feeding, h/day & 13 & 1.9798 & 0.6559 & 0.0872
\end{tabular}

Note. See text for explanation of sensitivity computations
Statistical Analysis

Data were checked for normality (Kolmogorov-Smirnov test) and homocedasticity (Levene's test). Analysis of covariance (ANCOVA), with chick age as a covariate, followed by post hoc Tukey tests, was used to assess the influence of (1) breeding habitat (sandy beaches and salinas), (2) breeding location (Barreta barrier island, Armona barrier island, Ancão peninsula, and salinas of Sta. Luzia), and (3) study year (2004 or 2005) on the mercury concentration in down feathers of chicks $<5$ days old. To test the null hypothesis that there were no differences in mean mercury concentration among prey species across (1) habitats (sandy beaches and salinas) and (2) prey species group (crustacean, pelagic, bottom, and euryhaline species), two-way analysis of variance (ANOVA), followed by post hoc Tukey tests for unequal sample size, was used. A Spearman correlation was applied to analyze the relationship between the amount of different prey groups in the diet (pelagic, bottom, and euryhaline fish and crustacea) and the mercury concentration in breast feathers of chicks aged 4 and 9 days. A one-way ANOVA was used to investigate differences in mercury content among $A-, B-$, and $C$-chicks at 0 days of age (hatching day). For model calibration with data collected during the 2005 breeding season, Model II regressions, a recommended procedure whenever both variables are subject to error, was used (Sokal and Rohlf 1995). The significance of the regressions was checked with ANOVA because analysis of variance is the only means of testing it in Model II regression (Fowler et al. 1998). The null hypothesis that the intercept of the estimated regressions is not significantly different from 0 , and the slope is not significantly different from 1, was tested using the Dent and Bleckie (DBK; 1979) regression test, which simultaneously tests the slope and the intercept. All analyses were performed with statistica v. 6.0 (Statsoft 1996) with a significance level of $p<0.05$. Data are presented as mean \pm standard deviation.

\section{Results}

Influence of Breeding Habitat and Location on Mercury Concentration in Chicks

Considering samples taken in 2004 (different beaches and salinas), there was no significant effect of breeding location (ANCOVA: $F_{3,24}=1.64, \quad p=0.20$ ) and habitat $\left(F_{1,26}=0.67, p=0.42\right)$ on the mercury concentration of chicks $<5$ days old. When we compared 2004 and 2005, and removed salinas at Arraial Ferreira Neto (not sampled in 2005) and the barrier island of Armona (not sampled in 2004), the result was not significant $\left(F_{1,64}=0.49\right.$, 
$p=0.48)$. For 2005 only, we found significant differences in the mercury concentration of chicks $<5$ days of age between sandy beaches and salinas $\left(F_{1,61}=4.64\right.$, $p=0.04)$ and among breeding locations $\left(F_{3,59}=10.18\right.$, $p=0.00$; Fig. 1). The mean mercury concentration of chicks from Armona was approximately twofold higher than that of chicks from other areas (Fig. 1).

\section{Mercury in Prey}

Lagoon prey had a significantly higher mercury concentration $\left(0.18 \pm 0.09 \mu \mathrm{g} \mathrm{g}^{-1}\right.$ d.w. $)$ than prey from salinas $\left(0.06 \pm 0.03 \mu \mathrm{g} \mathrm{g}^{-1}\right.$ d.w. $)$ and the sea $\left(0.06 \pm 0.03 \mu \mathrm{g} \mathrm{g}^{-1}\right.$ d.w., 1 -Way ANOVA: $F_{2,40}=16.49, p=0.00$ ). Comparing species groups, the mercury content was significantly higher for bottom fish $\left(0.17 \pm 0.10 \mu \mathrm{g} \mathrm{g}^{-1}\right.$ d.w. $)$ than for pelagic fish $\left(0.08 \pm 0.06 \mu \mathrm{g} \mathrm{g}^{-1}\right.$ d.w. $)$, euryhaline fish $\left(0.04 \pm 0.02 \mu \mathrm{g} \mathrm{g}^{-1} \mathrm{~d}\right.$.w. $)$, and crustacea $(0.08 \pm 0.03 \mu \mathrm{g}$ $\mathrm{g}^{-1}$ d.w.; $F_{3,39}=5.88, p=0.00$ ) (Fig. 2). These results are also in agreement with those for Sardina pilchardus (pelagic marine prey), Mugillidae (pelagic lagoon prey), and Paleomonetes varians (salinas prey), which had a lower mean mercury content than Gambusia holbrooki, a characteristic benthic prey (Table 2).

\section{Contribution of Diet to Mercury Content in Chicks}

Because mercury in early hatched chicks is mainly due to the egg mercury content (Becker et al. 1993), and consequently a reflection of female's mercury levels, we began to analyze differences of mercury concentration in chick feathers from 4 days of age onward, because these levels should be a reflection of their diet. There was a significant negative correlation between the mercury concentration in chick feathers and the percentage of pelagic fish on the diet of chicks at 4 days of age $\left(r_{s}=-0.69, p=0.03 ; n=10\right)$. Also, the amount of crustacean plus bottom fish in the diet

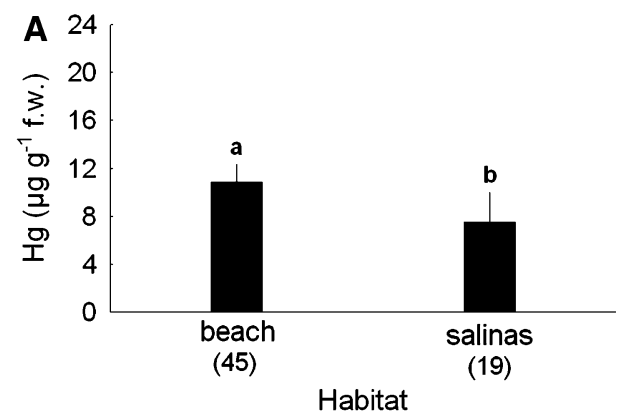

Fig. 1 Mercury concentrations ( $\mu \mathrm{g} \mathrm{g}^{-1}$ f.w.) in feathers of little tern chicks $<5$ days old from 2005 in relation to breeding habitat $(\mathbf{A})$ and location (B). Mean value $\pm \mathrm{SD}$, with sample size in parentheses. BAR, Barreta barrier island; ARM, Armona barrier island; PRF, of chicks at 9 days of age was significantly correlated with the mercury concentration in chick feathers $\left(r_{s}=0.67\right.$, $p=0.05 ; n=9)$.

\section{Mercury Calibration Model}

The mercury concentration in feathers of $A$-chicks decreased faster than that in $B$ - and $C$-chicks, but all chicks attained a similar amount of mercury from 14 days onward. At hatching, the $A$-chicks had a higher mercury content than $B$ - and $C$ - chicks did (one-way ANOVA: $F_{2,17}=7.25, p=0.001$ ) (Fig. 3).

The mercury decrease in feathers of little tern chicks predicted by the model for $A$-, $B$-, and $C$-chicks agreed well with the observed data for 2005 . This decrease was better predicted for $A$-chicks than for $B$ - and $C$-chicks, because all points predicted for $A$-chicks were within standard deviation lines. This model had significant Model II regressions between predicted and observed values for $A-, B-$, and $C$ chicks in 2005 (ANOVA: $F_{1,3}=74.15, p=0.003$, $r^{2}=0.96 ; \quad F_{1,3}=18.20, \quad p=0.02, \quad r^{2}=0.86 ; \quad$ and $\left.F_{1,3}=32.56, p=0.01, r^{2}=0.92\right)$. Furthermore, the slope of the regression was not significantly different from 1 and the intercept was not significantly different from 0 for $A-$, $B$-, and $C$-chicks (DBK regression test: $F_{1,3}=60.45$, $p=0.005 ; \quad F_{1,3}=15.32, \quad p=0.03 ; \quad$ and $F_{1,3}=29.90$, $p=0.01$ ), giving credibility to our model (Fig. 4).

\section{Sensitivity Analysis}

Sensitivity analysis revealed that the constant of mercury decrease was the most sensitive parameter, followed by the intercept of mercury decrease (both were obtained from the logarithmic calibrated formula for mercury decrease applied in the model) and the number of daylight hours that parents used for delivering the food to their chicks (Table 3). Changes of $\pm 10 \%$ in each of these three parameters caused

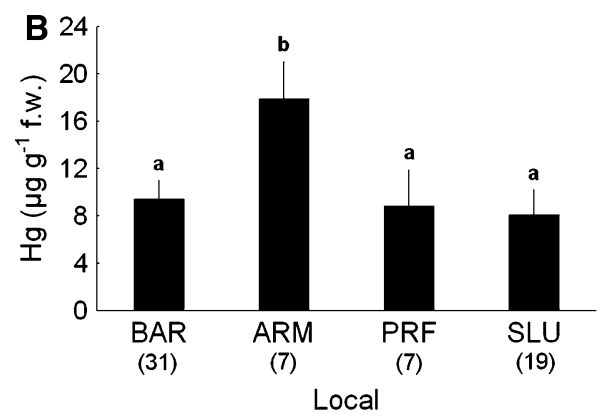

Ancão peninsula; SLU, Sta. Luzia salinas. Different lowercase letters indicate significant differences in mercury concentration. One-way ANCOVA with age as a covariate followed by post hoc Tukey test for unequal $N$ s at $p<0.05$ 


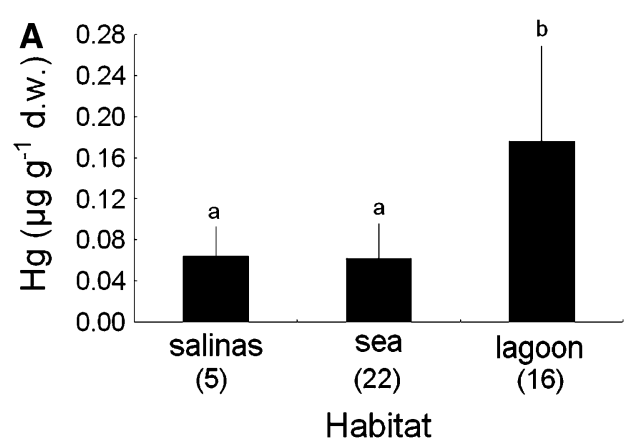

Fig. 2 Mercury concentrations ( $\mu \mathrm{g} \mathrm{g}^{-1}$ d.w.) in different prey of little tern chicks in relation to habitat $(\mathbf{A})$ and species group $(\mathbf{B})$. Mean value $\pm \mathrm{SD}$, with sample size in parentheses. Different lowercase

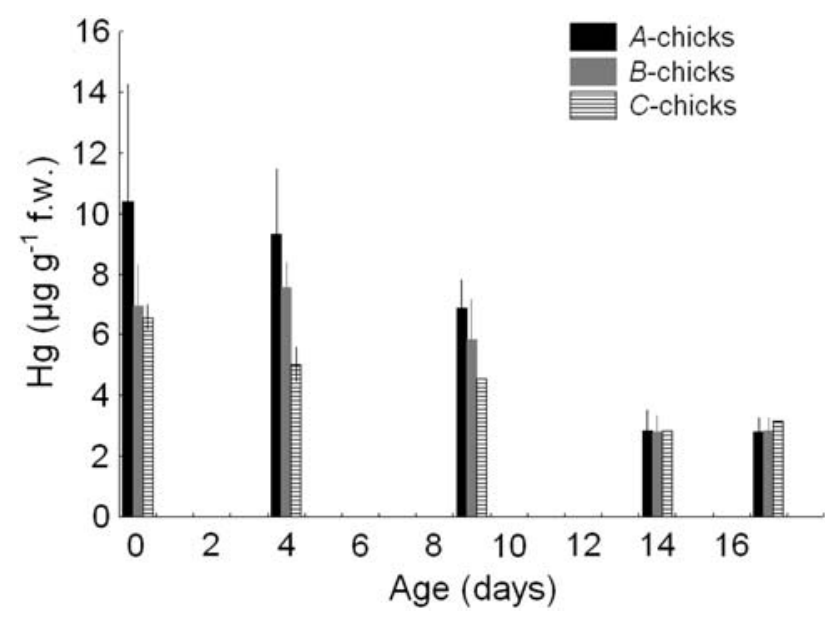

Fig. 3 Mercury concentration (fresh weight; f.w.) in feathers of little tern $A-, B$-, and $C$-chicks from Sta. Luzia salinas, in relation to age. Mean value \pm SD

$\pm 10 \%$ variation in the mercury concentration in the chick feathers. $A$-chicks were more sensitive to the constant of mercury decrease, followed by $B$ - and $C$-chicks. The same pattern was noticed for the effect of alterations on the feeding hours per day for all three groups of chicks, whereas changes in the intercept of mercury decrease affected more $B$-chicks than $A$ - and $C$-chicks.

\section{Theoretical Scenarios}

Considering a diet restricted to the lagoon prey (Pomatoschistus spp., Fundulus spp., and Atherina spp.) and accounting for the specific foraging time of the former three prey plus an extra foraging time that is gained by not foraging on the omitted prey (Stienen and Brenninkmeijer 2002) (Table 2), $A$ - and $B$-chicks may potentially have to deal with an excess of mercury on their body, because the capacity of dilution (by chick growth) and excretion to feathers would be exceeded. Across this scenario, only $C$ -

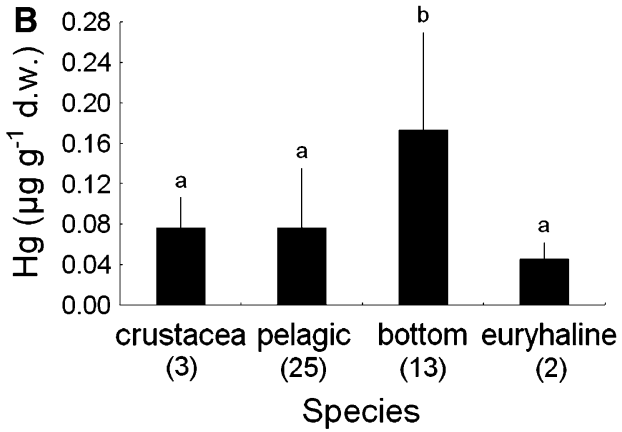

letters indicate significant differences in mercury concentration. Oneway ANOVA followed by post hoc Tukey test for unequal $\mathrm{Ns}$ at $p<0.05$

chicks would be maintained in a good situation, as they have much less mercury content at hatching. On the contrary, a diet restricted to marine prey (Sardina pilchardus, Belone belone, and Scomberesox saurus) would allow a decrease in the mercury concentration in chick feathers during chick growth (Fig. 5). Similarly a diet restricted to shrimp (crustacea, Paleomon spp., and Paleomonetes spp.) would enable low levels of mercury for chicks at 17 days of age. On the contrary, a diet of exclusively fish would lead to abnormal high levels of mercury, at least for $A$ chicks (Burger and Gochfeld 1997) (Fig. 5).

A diet solely of pelagic fish (Sardina pilchardus, Atherina spp., Belone belone, and Scomberesox saurus) would result in an increase in mercury levels in feathers as chicks aged. However, only an exclusive diet of bottom prey (Pomatoschistus spp. and Fundulus spp.) would increase the mercury levels for $B$-chicks (above the typical mercury decrease curve for 2005 chicks) and likely reach abnormal high levels for $A$-chicks (from 17 days onward; Fig. 5).

We identified the prey that contributed the most to reaching abnormally high mercury contamination levels in little tern chicks by restricting the diet of chicks to only one of the major prey delivered by parents on 2005. Assuming that parents feed their chicks solely on Pomatoschistus spp. (spending $0.37 \mathrm{~h}$ to deliver one item of this species to the nest) or on Atherina spp. (foraging trip duration $=0.47 \mathrm{~h}$ ), the whole brood ( $A-, B$-, and $C$-chicks) would reach possibly adverse levels of mercury contamination. Assuming that parents deliver to their chicks the same proportion of each prey that they feed themselves (Catry et al. 2006), the good condition of all chicks in the brood could be compromised (Fig. 5).

\section{Discussion}

Our results have shown that the mercury concentration in feathers of chicks raised in sandy beaches was higher than 
2005 A-chicks

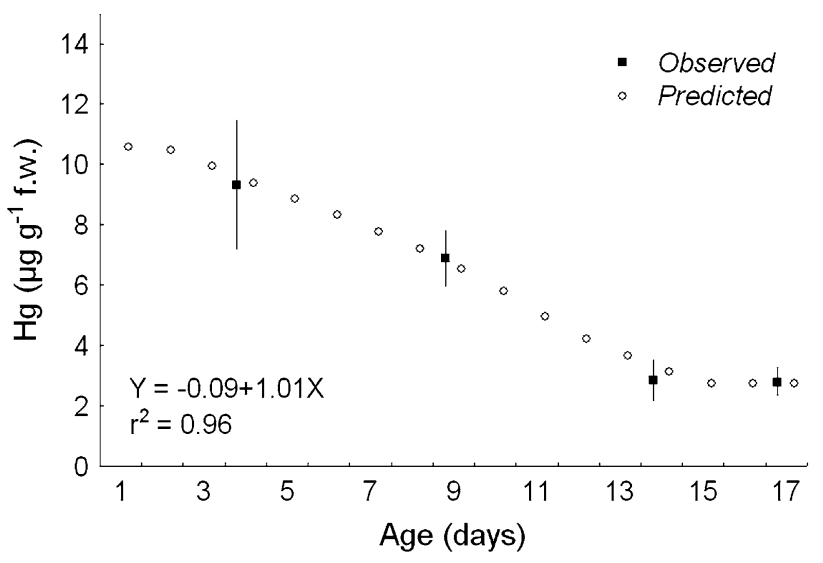

2005 B-chicks
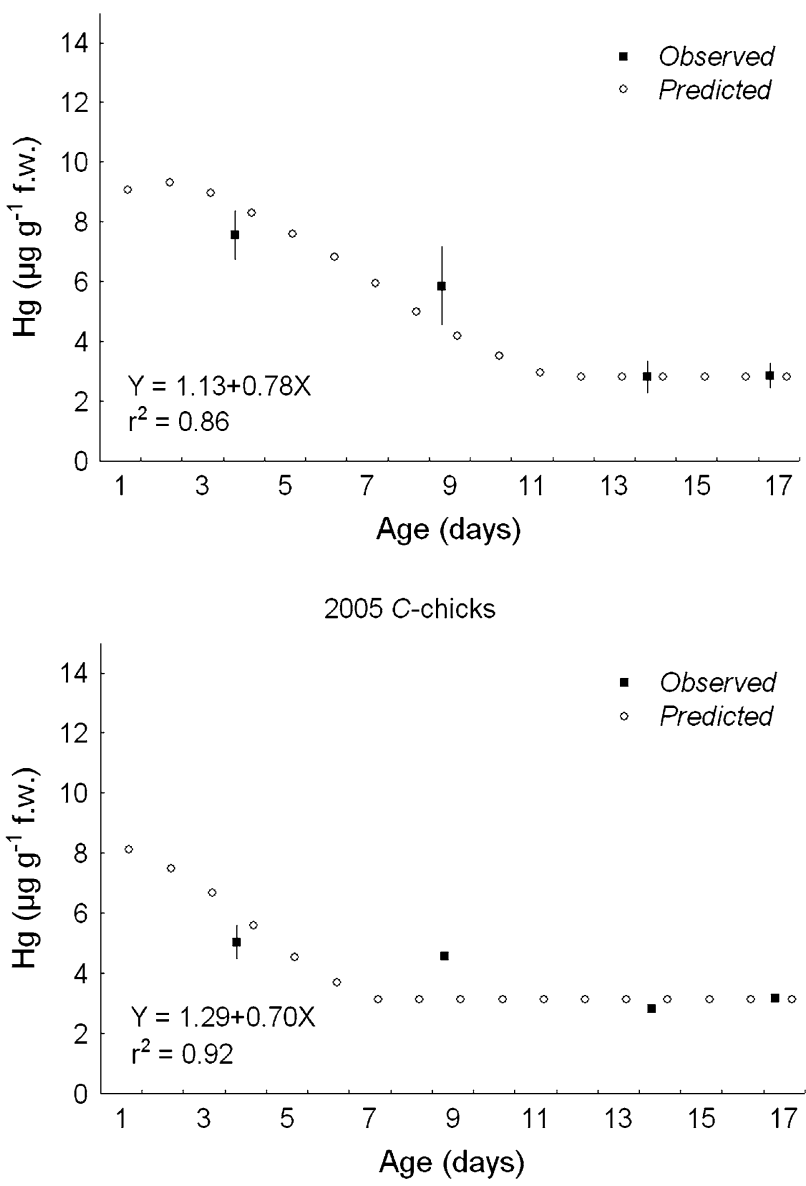

Fig. 4 Graphical representation of observed data (collected in 2005) and model predictions for mercury concentration (fresh weight; f.w.) in feathers of $A-, B$-, and $C$-chicks as they aged. Also shown are the regression results and equations for the three types of chicks within the brood (model calibration)

that of chicks raised in salinas. This difference was mainly explained by the significantly higher mercury levels of chicks from Armona barrier island. In chicks $<5$ days of age, mercury levels were related not only to items delivered by their parents (Goutner and Furness 1997) but also to mercury burdens present in their eggs (transmitted from their female parents [Becker et al. 1993]). Our results may be explained by the fact that adults breeding on Armona barrier island foraged much more in the lagoon than in the sea (Paiva et al. 2007). The same did not occur for other sandy beaches, Barreta barrier island, or Ancão peninsula, where birds were frequently sighted feeding at sea (Paiva et al. 2007; personal observation). Adult foraging around a sanitary discharge on the mainland in front of Armona may also explain the higher mercury content of chicks from Armona.

Overall, our results from chick feathers that mainly fed on prey from the lagoon are in agreement with the higher concentration of mercury present in prey from the lagoon than in prey from the adjacent sea. In Ria Formosa and other Portuguese wetlands typical prey groups from the lagoon (mostly benthic) had significantly higher levels of mercury than prey groups from the adjacent sea (mostly pelagic). According to Braune (1987), birds feeding on pelagic invertebrates accumulate significantly lower mercury levels than birds feeding on benthic organisms or piscivorous birds. This is associated with mercury bioamplification along the food web. A high degree of variation may also be found within piscivorous birds. The coefficient between predator and prey contamination levels, the biomagnification factor (BMF), given as the ratio between the concentration in the tissues of an organism and that in respective prey(s), may vary with species, habitat, prey availability, age, and other factors influencing type of prey captured (Gray 2002). Several studies have related potential prey, trophic level, and mercury levels. As the mercury bioaccumulates in prey, its concentration increases in predator species (Jarman et al. 1996; Muir et al. 1999; Dietz et al. 2000; Borga et al. 2006), revealing a deeper gradient in the water column from the pelagic area to the benthic zone (Thompson et al. 1998; Monteiro et al. 1999). Monteiro and Furness (2001) estimated that a dose of approximately $1 \mu \mathrm{g} \mathrm{Hg}$ f.w. in food items was necessary to increase by a factor of nine the feather's burden of mercury $\left(0.8 \mu \mathrm{g} \mathrm{g} \mathrm{g}^{-1}\right.$ f.w.) in chicks of Calonectris diomedea. Monteiro et al. (1998) observed that mean values for BMF varied between 125 and 225 in several seabirds and that the mean value for BMF in Calonectris diomedea was 132. In our study, little tern chicks feeding on prey with mercury levels of $0.03-0.31 \mu \mathrm{g} \mathrm{g}^{-1}$ d.w. revealed mercury levels in feathers of 1.94-16.53 $\mu \mathrm{g} \mathrm{g}^{-1}$ f.w., which gives a BMF varying from 53.32 to 64.67 .

The mercury concentration in feathers decreased strongly from $A$ - to $B$ - and $C$-chicks, as they aged from 0 to 17 days. In addition, the mercury concentration in feathers of newborn little tern $A$-chicks (at their hatching age, 0 days) was significantly higher than that in newborn $B$ - 
Fig. 5 Various theoretical scenarios of the amount of mercury (fresh weight; f.w.) that little tern $A-, B$-, and $C$-chicks might allocate to their breast feathers if their diet could be restricted to some prey items. The typical logistic mercury decline curve for 2005 chicks is presented for comparison. The solid top line represents the maximum value of $20 \mu \mathrm{g} \mathrm{g}^{-1}$ f.w. of mercury in feathers detected in 2005 in the salinas of Sta. Luzia. Lagoon prey: Pomatoschistus spp (POM), Fundulus spp (FUN), and Atherina spp (ATH). Marine prey: Sardina pilchardus (SAR), Belone belone (BEL), and Scomberesox saurus (SCO). Crustacea (shrimp; SHR):

Paleomon spp. and Paleomonetes spp. Pelagic prey: SAR, ATH, BEL, and SCO. Bottom prey: POM and FUN. Adult diet: $45.9 \%$ POM, $40.5 \%$ ATH, and $13.6 \%$ SHR
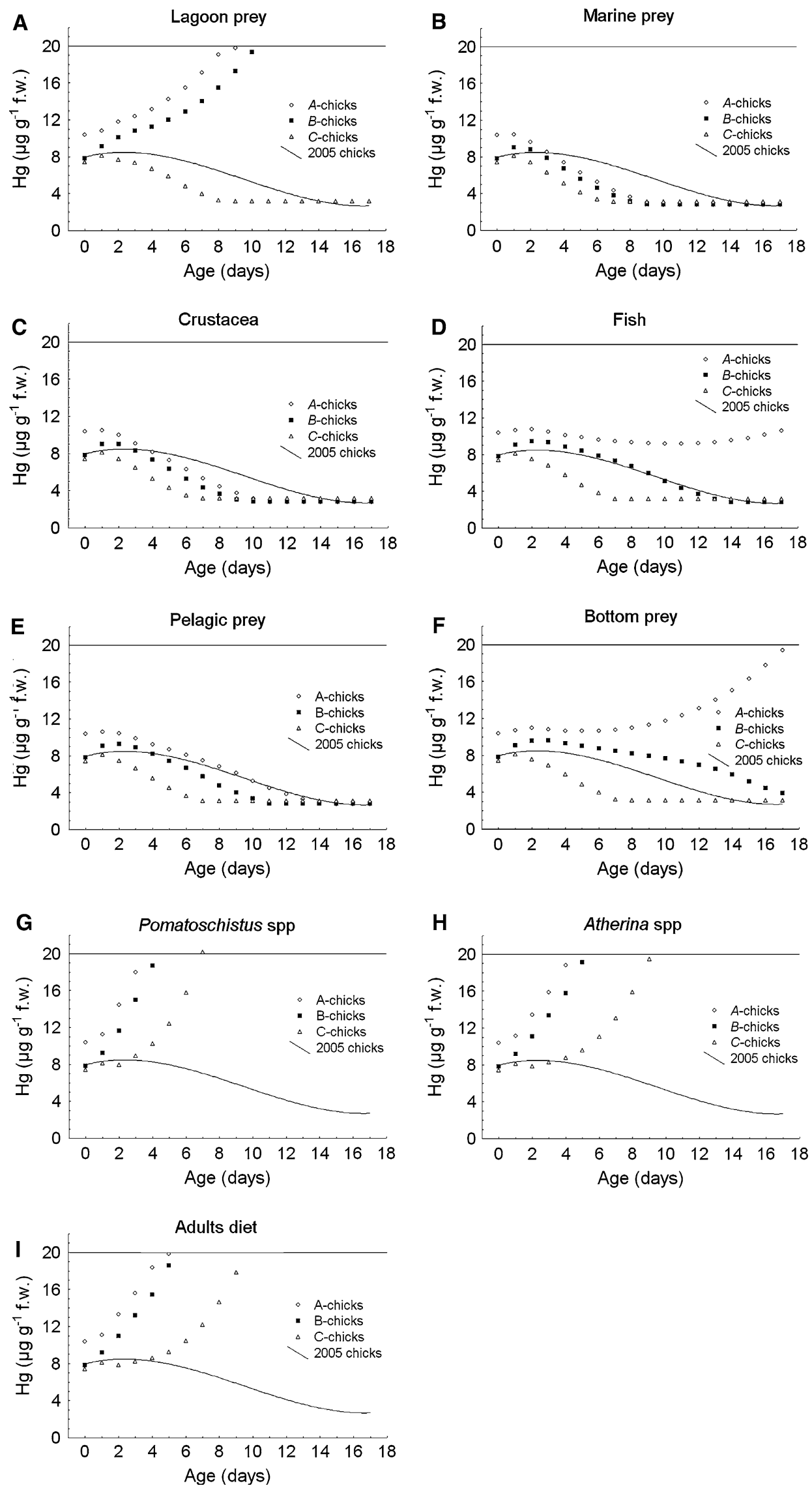
and $C$-chicks (Becker et al. 1994), strengthening the idea that the mother excretes the majority of accumulated mercury into the first egg laid, as subsequent eggs normally have a much lower mercury content (Becker 1992). This high level of mercury could be supplanted by a higher dilution effect generated by the faster body growth in the case of $A$-chicks (Paiva et al. 2006a). A-chicks were fed alone for almost 1 day (Paiva et al. 2006b) and therefore assimilated all food delivered by parents. Also, larger chicks may exhibit advantages over other chicks during food delivery. Little tern chicks revealed a large reduction in mercury concentration with age in relation to other birds, e.g., aquatic birds like Ardeola ralloides (Goutner et al. 2001) or seabirds such as Sterna paradisaea, Rissa tridactyla, and Uria aalge (Stewart et al. 1997), but were similar to their Azorean relatives (Sterna dougallii and Sterna hirundo [Monteiro et al. 1995]).

We successfully modeled mercury decline in feathers of growing $A$-, $B$-, and $C$-chicks. This allowed us to examine some diet scenarios by manipulating the diet inputs (changing the quantity and quality of prey items) and examining the amount of mercury content in plumage. Other studies used several seabird species to establish relationships between diet and body mercury concentrations (Monteiro et al. 1998) or manipulated the diet of chicks raised partly or totally in captivity (e.g., Monteiro and Furness 2001; Kenow et al. 2003). Naturally, the model was more sensitive to parameters related to the mercury decline formula, namely, the constant that drove mercury levels in feathers and the intercept value of that formula. The number of hours that parents have available to actively feed their chicks was also important to explain mercury levels in chicks, as this will linearly increase the numbers of prey delivered and therefore the amount of mercury that chicks receive. We used a constant number of daylight hours for parents to deliver food at a constant rate, which varied among prey species. This does not match the reality because parents will probably reduce their feeding rate when chicks are well-fed. The only way to better simulate reality would be to account for chicks being foodlimited. Data on the amount of food that drives chicks to stop begging were not available for this species. Theoretical scenarios tested with the constructed mercury model agreed with the results of mercury contamination in the different prey species groups, suggesting that, for example, if chicks were raised only on lagoon prey, they might encounter problems in their condition. At least $A$ - and $B$ chicks would reveal adverse effects if they were fed solely with lagoon prey, as mercury contamination would have not been diluted through excretion to feathers and body growth as referred to by Becker et al. (1994). On the contrary, chicks will not experience large adverse effects if they are fed with prey captured in the sea, which are also the most important (in energetic terms) for their growth (Paiva et al. 2006b).

The importance of salinas as alternative breeding and feeding sites (Catry et al. 2004; Paiva et al. 2006b) is highlighted by the effect that crustacean prey from salinas (Paleomonetes spp.) had on chicks' mercury levels, which results from the balance between mercury intake by food ingestion and the dilution effect of growth, compared to a diet restricted only to fish (at least $A$-chicks will suffer from a fish-only diet). Becker et al. (2002) discussed the effect of the ingestion of crustacean (mainly shrimp) in decreasing the amount of mercury input by food intake in chicks. Seabird chicks such as those of little terns need to be supplied with a specific and varied diet, different from that of their parents (Catry et al. 2006). This has been attributed to their developmental restriction to ingest only smaller and thinner prey items (Bogliani et al. 1994; Ramos et al. 1998; Paiva et al. 2006a). However, our model also suggests that if little tern chicks were fed solely on a diet similar to that of the adults, they would ingest such high mercury levels that their normal development could be affected. This is because Pomatoschistus spp. and Atherina spp., the most important prey for adults (Catry et al. 2006), had the highest mercury concentration.

Studies relying on molecular biomarkers have contributed new information on mercury effects at a cellular level. Mercury concentrations between 2 and $4 \mu \mathrm{g} \mathrm{g}^{-1}$ d.w. were associated with DNA damage in organisms of lower trophic levels like invertebrates (Benton et al. 2002). Moreover, the relation between contaminants like mercury and the variation of DNA content in great blue heron eggs was investigated (Custer et al. 1997). Other studies have already considered that mercury levels $\geq 5 \mu \mathrm{g} \mathrm{g}^{-1}$ d.w. in feathers may represent deleterious effects in birds' metabolism (Burger and Gochfeld 1997).

\section{Conclusions}

The findings of this study raise again the importance of pelagic marine prey for estuarine birds, not only for their "normal" growth (Paiva et al. 2006b) but also for provision of a food resource with lower contamination levels. This enhances the importance of sandy beaches for breeding little terns (Catry et al. 2004), where birds have better access to marine prey (Paiva et al. 2006b). Crustacean prey obtained in salinas, Paleomonetes spp., are less important in energetic terms (Paiva et al. 2006b), but they may also contribute to the lower mercury levels of chicks raised in salinas. Prey captured in the lagoon, mainly benthic fish, may be considered an important contributor to flux of mercury to chicks of little terns breeding in salinas. The contribution of this type of food may have 
consequences, in particular, during the first period (from 0 to 4 days) of chick growth, especially for $A$ - and $B$-chicks, to which mercury levels may be harmful.

The fast growing rates in little tern chicks and the related dilution effect seem to decrease mercury levels, which may prevent some deleterious effects in completely grown chicks if the habitat is not largely polluted. However, if pollution levels are high and persistent in the lagoon, and chicks are mainly fed prey from the lagoon, the mercury entering the chick body by food ingestion may not be sufficiently balanced by the dilution effect. This model may have a wider application in similar seabird species breeding in coastal environments.

Acknowledgment We are grateful to David Max and two anonymous referees for valuable comments on a draft version of the manuscript.

\section{References}

Allcorn R, Eaton MA, Cranswick PA, Perrow M., Hall C., Smith L, Reid J, Webb A, Smith KWS, Langston RHW, Ratcliffe N (2003) A pilot study of breeding tern foraging ranges in NW England and East Anglia in relation to potential development areas for offshore windfarms. RSPB/WWT/JNCC, Sandy

Arcos JM, Ruiz X, Bearhop S, Furness RW (2002) Mercury levels in seabirds and their fish prey at the Ebro Delta (NW Mediterranean): the role of trawler discards as a source of contamination. MEPS 232:281-290

Bearhop S, Waldron S, Thompson DR, Furness RW (2000) Biamplification of mercury in great skua Catharacta skua chicks: the influence of trophic status as determined by stable isotope signatures of blood and feathers. Mar Pollut Bull 40(2):181-185

Becker PH (1992) Egg mercury levels decline with the laying sequence in charadriiformes. Bull Environ Contam Toxicol 48:762-767

Becker PH, Furness RW, Henning D (1993a) Mercury dynamics in young common tern (Sterna hirundo) chicks from a polluted environment. Ecotoxicology 2:33-40

Becker PH, Furness RW, Henning D (1993b) The value of chick feathers to assess spatial and interspecific variation in the mercury contamination of seabirds. Environ Monit Assess 28:255-262

Becker PH, González-Solís J, Behrends B, Croxall J (2002) Feather mercury levels in seabirds at South Georgia: influence of trophic position, sex and age. Mar Ecol Prog Ser 243:261-269

Becker PH, Henning D, Furness RW (1994) Differences in mercury contamination and elimination during feather development in gull and tern broods. Arch Environ Contam Toxicol 27:162-167

Benton MJ, Mallot ML, Trybula MJ, Dean DM, Guttman SI (2002) Genetic effects of mercury contamination on aquatic snail populations: allozyme genotypes and DNA strand breakage. Environ Toxicol Chem 21(3):584-589

Bogliani G, Fasola M, Canova L, Saino N (1994) Prey selection by parents and chicks of the little tern Sterna albifrons. Avocetta 18:9-11

Borga K, Campbell L, Gabrielsen GW, Norstrom RJ, Muir DCG, Fisk AT (2006) Regional and species bioaccumulation of major and trace elements in artic seabirds. Environ Toxicol Chem 25:29272936
Braune BM (1987) Comparison of total mercury levels in relation to diet and molt for nine species of marine birds. Arch Environ Contam Toxicol 16:217-224

Burger J, Gochfeld M (1997) Risk, mercury levels, and birds: relating adverse laboratory effects to field monitoring. Environ Res $75: 160-172$

Burger J, Gochfeld M (2002) Effects of chemicals and pollution on seabirds. In: Schreiber EA, Burger J (eds) Biology of marine birds. CRC Press, Boca Raton, FL

Burger J, Gochfeld M (2004) Marine birds as sentinels of environmental pollution. EcoHealth 1:263-274

Catry T, Ramos JA, Catry I, Revez M-A, Grade N (2004) Are salinas a suitable alternative breeding habitat for little terns? Ibis 146:247-257

Catry T, Ramos JA, Martins J, Peste F, Trigo S, Paiva VH, Almeida A, Luís A, Palma J, Andrade P (2006) Intercolony and annual differences in the diet and feeding ecology of little tern adults and chicks in Portugal. Condor 108:366-376

Cramp S (1985) The birds of the western Paleartic. Vol 4. Oxford University Press, Oxford

Custer TW, Hines RK, Melancon MJ, Hoffman DJ, Wickliffe JK, Bickham JW, Martin JW, Henshel DS (1997) Contaminant concentrations and biomarker response in great blue heron eggs from 10 colonies on the upper Mississippi River, USA. Environ Toxicol Chem 16:260-271

Davies S (1981) Development and behaviour of little tern chicks. Br Birds 74:291-298

Dietz R, Riget F, Cleemann M, Aarkrog A, Johansen P, Hansen JC (2000) Comparison of contaminants from different trophic levels and ecosystems. Sci Tot Environ 245:221-231

Fasola M, Bogliani G (1990) Foraging ranges of an assemblage of Mediterranean seabirds. Colon Waterbirds 13(1):72-74

Fowler J, Cohen L, Jarvis P (1998) Practical statistics for field biology. Wiley, New York, p 259

Furness RW, Camphuysen KCJ (1997) Seabirds as monitors of the marine environment. ICES J Mar Sci 54:726-737

Goutner V, Furness RW (1997) Mercury in feathers of little egret Egretta garzetta and Night Heron Nycticorax nycticorax chicks and in their prey in the Axios Delta, Greece. Arch Environ Contam Toxicol 32:211-216

Goutner V, Furness RW, Papakostas G (2001) Mercury in feathers of squacco heron (Ardeola ralloides) chicks in relation to age, hatching order, growth and sampling dates. Environ Pollut 111:107-115

Gray JS (2002) Biomagnification in marine systems: the perspective of an ecologist. Mar Pollut Bull 45:46-52

High Performance Systems, Inc. (1997) Getting started with the STELLA software. A hands-on experience. High Performance Systems, Inc., Hanover, NH

Jarman WM, Hobson KA, Sydeman WJ, Bacon E, McLaren EB (1996) Influence of trophic position and feeding location on contaminant levels in the Gulf of the Farallones food web revealed by stable isotope analysis. Environ Sci Technol 30:654660

Kenow KP, Gutreuter S, Hines RK, Meyer MW, Fournier F, Karasov WH (2003) Effects of methyl mercury exposure on the growth of juvenile common loons. Ecotoxicology 12:171-182

Konarzewski M, Kooijman S, Ricklefs E (1998) Models for avian growth and development. In: Starck JM, Ricklefs RE (eds) Avian growth and development. Oxford University Press, New York

Lewis SA, Furness RW (1991) Mercury accumulation and excretion in laboratory reared black-headed gull Larus ridibundus chicks. Arch Environ Contam Toxicol 21:316-320

Lewis SA, Furness RW (1993) The role of eggs in mercury excretion by quail Coturnix coturnix and the implications for monitoring 
mercury pollution by analysis of feathers. Ecotoxicology 2:5564

Madenjian CP, Gabrey SW (1995) Waterbird predation on fish in western Lake Erie: a bioenergetics model application. Condor 97:141-153

Massias A, Becker PH (1990) Nutritive value of food and growth in common tern Sterna hirundo chicks. Ornis Scand 21:187-194

Monteiro LR, Furness RW (1995) Seabirds as monitors of mercury in the marine environment. Water Air Soil Pollut 80:851-870

Monteiro LR, Furness RW (2001) Kinetics, dose-response, excretion and toxicity of methylmercury in free-living Cory's shearwaters chicks. Environ Toxicol Chem 20(8):1816-1823

Monteiro LR, Furness RW, del Nevo AJ (1995) Mercury levels in seabirds from the Azores, mid-North Atlantic Ocean. Arch Environ Contam Toxicol 28:304-309

Monteiro LR, Granadeiro JP, Furness RW (1998) Relationship between mercury levels and diet in Azores seabirds. Mar Ecol Prog Ser 166:259-265

Monteiro LR, Granadeiro JP, Furness RW, Oliveira P (1999) Contemporary patterns of mercury in the Portuguese Atlantic inferred from mercury concentrations in seabird tissues. Mar Environ Res 47:173-156

Muir D, Braune B, DeMarch B, Norstrom R, Wagemann R, Lockhart L, Hargrave B, Bright D, Addison R, Payne J, Reimer K (1999) Spatial and temporal trends and effects of contaminants in the Canadian Artic marine ecosystem: a review. Sci Tot Environ 230:83-144

Paiva VH, Ramos JA, Catry T, Pedro P, Medeiros R, Palma J (2006a) Influence of environmental factors and energetic value of food on little tern chick growth and food delivery. Bird Study 53:1-11

Paiva VH, Ramos JA, Machado D, Penha-Lopes G, Bouslama MF, Dias N, Nielsen S (2006b) Importance of marine prey to growth of estuarine tern chicks: evidence from an energetic balance model. Ardea 94:241-255

Paiva VH, Ramos JA, Martins J, Almeida A, Carvalho A (2007) Foraging habitat selection by little terns Sterna albifrons in an estuarine lagoon system of southern Portugal. Ibis (in press)
Ramos JA, Solá E, Monteiro LR, (1998) Prey delivery to roseate tern chicks in the Azores. J Field Ornithol 69:419-429

Schew WA, Ricklefs RE (1998) Developmental plasticity. In: Starck JM, Ricklefs RE (eds) Avian growth and development. Oxford University Press, New York

Sokal RR, Rohlf FJ (1995) Biometry. 3rd ed. Freeman Press, New York

Starck JM, Ricklefs RE (1998) Patterns of development: the altricial-prcocial spectrum. In: Starck JM, Ricklefs RE (eds) Avian growth and development. Oxford University Press, New York

Stewart FM, Phillips RA, Catry P, Furness RW (1997) Influence of species, age and diet on mercury concentrations in Shetland seabirds. Mar Ecol Prog Ser 151:237-244

Stienen EWM, Brenninkmeijer A (2002) Variation in growth in sandwich tern chicks Sterna sandvicensis and the consequences for pre- and post-fledging mortality. Ibis 144:567-576

Tavares PC, Monteiro LR, Lopes RJ, Pereira ME, Duarte AC, Furness RW (2005) Mercury contamination of little tern Sterna albifrons chicks in South-west Europe. Brood, age and colony related effects. Bull Environ Contam Toxicol 74(1):177-183

Thompson DR, Furness RW (1989a) The chemical form of mercury stored in South Atlantic Seabirds. Environ Pollut 60:305-317

Thompson DR, Furness RW (1989b) Comparison of the levels of total and organic mercury in seabird feathers. Mar Pollut Bull 20(11):577-579

Thompson DR, Furness RW, Monteiro LR (1998) Seabirds as biomonitors of mercury inputs to epipelagic and mesopelagic marine food chains. Sci Tot Environ 213:299-305

Thyen S, Becker PH, Behmann H (2000) Organochlorine and mercury contamination of little terns (Sterna albifrons) breeding at the western Baltic Sea, 1978-96. Environ Pollut 108(2):225238

Wenzel C, Adelung D, Theede H (1996) Distribution and age-related changes of trace elements in kittiwake Rissa tridactyla nestlings from an isolated colony in the German Bight, North Sea. Sci Tot Environ 193:13-26 